\title{
Estimasi Carrier Ferquency Offset menggunakan Timing Metric pada Sinyal OFDM
}

\author{
Yolen Perdana Sari ${ }^{1}$, Shelvi Eka Tassia ${ }^{2}$ \\ ${ }^{1,2}$ Teknik Informatika, Universitas Pamulang \\ Jl. Surya kencana no 1, Pamulang, Tangerang Selatan \\ e-mail: 1dosen01705@unpam.ac.id,2dosen01768@unpam.ac.id
}

\begin{abstract}
OFDM is one of technology that can be utilized in a variety of telecommunication systems that being widely developed today, for application in LAN, WLAN, 3G, 4G, or 5G. One of the problem faced by the OFDM technology that its sensitivity to Carrier Frequency Offset (CFO) and the lack of synchronization in the OFDM signal. This research aims to design the synchronization that estimates Carrier Frequency Offset (CFO) to obtain synchronization of OFDM signal, where the error of the estimated Carrier Frequency Offset can be obtained, minimized and better than previous studies. The CFO estimation method in this research is using the training symbol on the OFDM symbol and utilize the statistical characteristics of the timing metric. This researchs result shows the Mean Square Error (MSE) of estimated Carrier Frequency Offset to Carrier Frequency Offset input, with range MSE $9.43 \times 10^{-3}$ at 0 dB SNR input and MSE $1.687 \times 10^{-5}$ at $30 \mathrm{~dB}$ SNR input. If Signal to Noise Ratio is greater, then the value of the mean square error (MSE) will be smaller. The position of the timing metric for timing estimation also affects to CFO estimation. CFO estimation accuracy will be maximized when using maximum timing metric.
\end{abstract}

Keywords: OFDM; Timing Metric; Mean square error; Signal to Noise Ratio; Carrier frequency Offset

\section{Abstrak}

OFDM merupakan salah satu teknologi yang dapat dimanfaatkan dalam berbagai sistem komunikasi jarak jauh yang sedang banyak berkembang saat ini, baik pada LAN, WLAN, 3G, ataupun 4G atau 5G. Salah satu masalah yang dihadapi oleh teknologi OFDM yang merupakan kelemahan dari sistem OFDM itu sendiri yaitu sensitif terhadap carrier frequency offset (CFO) dan sulitnya sinkronisasi sinyal pada OFDM. Penelitian ini bertujuan untuk merancang dan mensimulasikan estimasi carrier frequency offset (CFO) sehingga didapatkan estimasi carrier frequency offset yang lebih baik dan error dari estimasi carrier frequency offset bisa ditekan seminimal mungkin. Metode estimasi CFO yang digunakan adalah dengan memakai training symbol pada simbol simbol OFDM dan memanfaatkan karakteristik statistik pada timing metric. Dari hasil penelitian didapatkan mean square error (MSE) estimasi CFO terhadap CFO masukan yang cukup bagus, yakni berkisar adalah $9.43 \times 10^{-3}$ pada SNR masukan $0 \mathrm{~dB}$ dan pada SNR masukan $30 \mathrm{~dB}$ dengan MSE $1.687 \times 10^{-5}$. Dimana semakin besar Signal to Noise Ratio, maka semakin kecil nilai dari mean square error (MSE). Posisi timing metric yang digunakan juga mempengaruhi hasil estimasi CFO yang dilakukan. Akurasi estimasi CFO akan maksimal ketika menggunakan timing metric maksimum.

Kata Kunci: OFDM; Timing Metric; Mean square error; Signal to Noise Ratio; Carrier frequency offset

\section{Pendahluan}

Modulasi adalah teknologi yang berperan penting dalam teknologi komunikasi jarak jauh. Berbagai teknologi modulasi yang ada memberikan kelebihan dan kekurangannya masing- masing. Termasuk sistem modulasi yang semakin berkembang saat ini yaitu OFDM atau
Orthogonal Frequency Division Multiplexing. OFDM adalah modulasi yang dipakai pada siste, $\mathrm{m}$ komunikasi $3 \mathrm{G}, 4 \mathrm{G}$, ataupun $5 \mathrm{G}$.

OFDM memiliki prinsip kerja utama yaitu pembagian aliran data kecepatan tinggi kedalam aliran data kecepatan rendah kemudian dikirimkan secara terus menerus dan bersamaan melalui 
beberapa subcarrier. OFDM (Orthogonal Frquency Division Multiplexing) adalah salah satu skema MCM (Multicarrier modulation) dengan menggunakan beberapa subcarrier secara paralel. Subcarrier pada sistem OFDM dapat dibuat overlap karena memiliki sifat orthogonalitas satu dengan lainnya.

Orthogonal Frequency Division Mulplexing (OFDM) adalah sistem yang mempunyai kapasitas tinggi dan tahan terhadap fading, tetapi rentan terhadap adanya Carrier Frequency Offset (CFO) yang diakibatkan oleh efek Doppler. Selain rentan terhadap CFO, permasalahan yang sering timbul dalam sistem OFDM adalah sulitnya sinkronisasi pada simbol OFDM. Pada penelitian ini mencoba untuk membuat simulasi estimasi $\mathrm{CFO}$ untuk mendapatkan nilai $\mathrm{CFO}$ yang dapat menekan error CFO seminimal mungkin.

Dari penelitian sebelumnya (Suyoto, 2015) dapat dilihat perbandingan dari metode estimasi CFO yang ada. Pada penelitian ini kami mencoba untuk menggunakan timing metric statistic dengan training symbol untuk nilai estimasi nilai CFO sehingga didapatkan error yang lebih sedikit dan SNR maksimum.

\section{Dasar Teori}

\subsection{Modulasi Multicarrier}

Modulasi multicarrier atau disingkat dengan MCM adalah prinsip pengiriman data dengan membagi data menjadi beberapa aliran bit, masing-masing memiliki kecepatan bit yang lebih rendah. Prinsip dasar transmisi multicarrier adalah menjadikan aliran data serial menjadi beberapa aliran paralel.

Modulasi multicarrier telah menarik perhatian dunia telekomunikasi sebagai salah satu sarana untuk meningkatkan kapasitas (bit/detik/Hz) komunikasi digital. Skema teknologi modulasi ini cocok digunakan untuk siaran audio, televisi digital, dan sebagai metode untuk memperoleh kecepatan data yang tinggi dalam sistem asymmetric digital subscriber line (ADSL).

\subsection{OFDM}

OFDM adalah salah satu skema MCM (Multicarrier modulation) yang merupakan cara pengiriman data yang memiliki kecepatan tinggi dengan memakai beberapa subcarrier yang disusun secara paralel. Input data mengalir ke banyak subcarrier yang saling paralel dan saling orthogonal dengan kecepatan data yang lebih rendah. Setiap subcarrier dibuat saling overlap satu dengan lainnya karena sifat subcarrier yang saling orthogonal.

Prinsip dasar OFDM adalah memecah data serial dengan bitrate tinggi (wideband) menjadi beberapa data paralel yang memiliki bitrate rendah (narrowband), data- data yang dipecah tersebut dimodulasi oleh masing-masing subcarrier (Cho, Yong Soo; dkk, 2010) Efisiensi spectrum frekuensi pada system OFDM lebih tinggi dari sistem modulasi lainnya karena subcarrier yang saling overlap.

Gambar 1 di bawah ini menjelaskan perbedaan spektrum FDM dan OFDM. OFDM bisa melakukan penghematan bandwith yang cukup signifikan hiingga 50\% di banding sistem MCM.

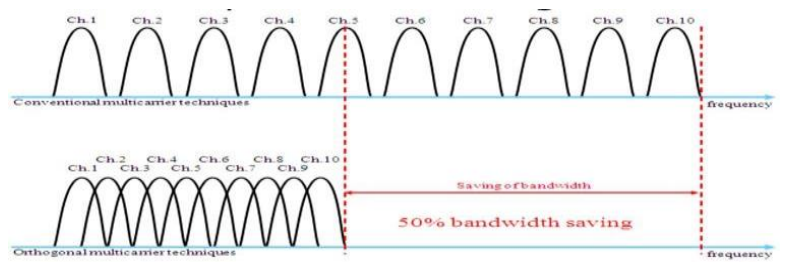

\section{Gambar 1 Perbendaan Spektrum MCM dan OFDM}

Untuk mengurangi kompleksitas tiap subcarrier-nya, OFDM memakai Inverse Discrete Fourier Transform (IDFT) sebagai modulator dan Discrete Fourier Transform (DFT) sebagai demodulator. Fenomena yang tak dapat dihindari pada sistem komunikasi radio adalah adanya efek multipath fading yang menyebabkan fluktuasi daya sinyal terima di receiver. Dengan menggunakan OFDM maka kanal yang bersifat frekuensi selective fading dirasakan sebagai flat fading oleh tiap-tiap subcarrier OFDM, oleh karena bandwidth subcarrier OFDM narrowband jika dibandingkan dengan bandwidth koheren kanal. Skema transmisi OFDM yang menggunakan IFFT dan FFT ditunjukan oleh gambar 2 di bawah.

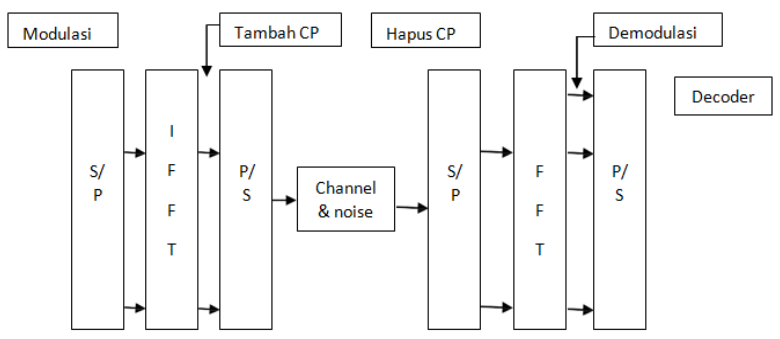

Gambar 2 Transmisi OFDM dengan FFT/IFFT (Cho, Yong Soo; dkk, 2010) 
Prinsip OFDM yaitu bit data masukan dibagi ke dalam beberapa $\mathrm{N}$ aliran simbol, kecepatan $1 / \mathrm{T}$, durasi simbol adalah $T_{S}, \quad N$ adalah jumlah subcarrier, durasi simbol OFDM adalah TOFDM, sehingga:

$$
T_{S} \square N . T_{O F D M} \text { roaa }
$$

\subsection{FFT dan IFFT}

Fast Fourier Transform (FFT) adalah suatu algoritma persamaan matematika untuk menggambarkan sinyal dalam domain frekuensi atau waktu diskrit. Pada proses Inverse Fast Fourier Transform (IFFT) sinyal diubah dari domain frekuensi menjadi domain waktu. Modulator atau pembuat symbol OFDM memakai IFFT, demodulator atau yang menguraikan sinyal OFDM memakai FFT. FFT dan IFFT adalah cara yang paling efisien untuk menghitung Discrete Fourier Transform (DFT) dan Inverse Discrete Fourier Transform (IDFT).

DFT N-point deretan $x(k), 0 \leq k \leq N-1$ dapat dihitung dengan persamaan berikut (Cho \& Park, 2014):

$$
\mathrm{X}(\mathrm{n})=\sum_{k=0}^{N-1} x(k) W_{N}^{k n} \quad n=0,1, \ldots N-1
$$

$X(n)$ adalah spectral diskrit ke- $n$ dan $\mathrm{WN}$ adalah $\mathrm{WN}=e^{-j 2 \pi / N}$, sehingga twiddle factor $W_{N}^{k n}$ dapat ditulis sebagai (Cho \& Park, 2014):

$$
W_{N}^{k n}=e^{-j 2 \pi k n / N}
$$

Dari persamaan 2.2 dapat dilihat bahwa $x(k)$ merupakan deretan kompleks, perhitungan langsung yang lengkap akan membutuhkan waktu yang lama, maka dimanfaatkan algoritma FFT dan IFFT untuk mempercepat proses.

DFT N-point bisa diekspresikan sebagai berikut (Cho \& Park, 2014):

$X(n)=\sum_{k=0}^{N / 2-1} x_{1}(k) W_{N / 2}^{k n}+W_{N}^{n} \sum_{k=0}^{N / 2-1} x_{2}(k) W_{N / 2}^{k n}$

Persamaan FFT dan IFFT dibedakan oleh koefisien di antara keduanya dan tanda minus pada IFFT. Kedua rumusan tersebut melakukan hal yang sama, yaitu mengalikan sinyal masukan dengan sinyal sinusoidal, kemudian dipisahkan. FFT dan IFFT adalah fungsi yang sama. Gambar 3 di bawah adalah IFFT/FFT pada blok diagram OFDM pada pengirim dan penerima

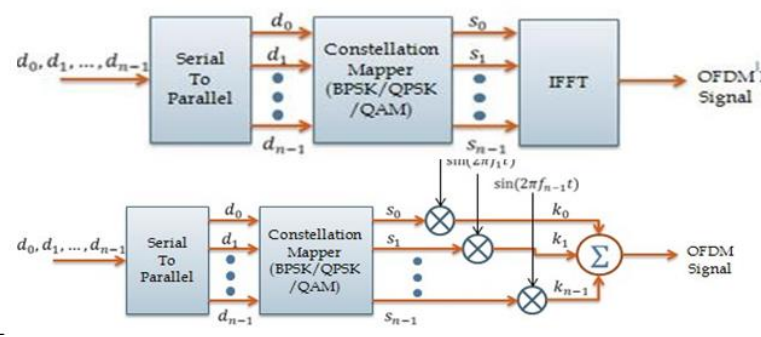

Gambar 3 Diagram Blok IFFT pada Transmiter

\subsection{Cyclic Prefix}

Kanal non ideal menyebabkan inter symbol interference (ISI) pada setiap saluran subcarrier karena pulsa yang tumpang tindih. Hal ini juga akan menyebabkan inter carrier interference (ICI) karena sinyal yang diterima yang tidak ortogonal. Menambahkan cyclic prefix untuk setiap simbol OFDM meringankan masalah ISI dan ICI. Gambar di bawah adalah penambahan Cyclic Prefix (CP) pada OFDM.

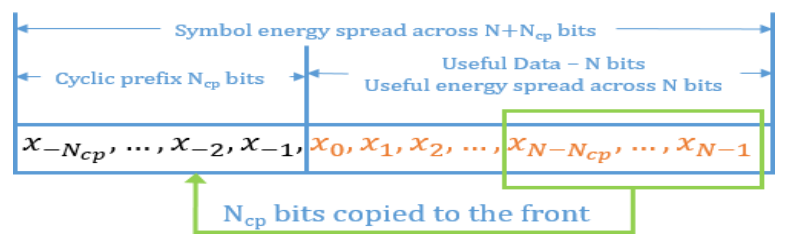

Gambar 4 Cyclic Prefix dalam OFDM

\subsection{Error Waktu dan Error Frekuensi dalam OFDM}

\subsubsection{Error Waktu}

Berdasarkan lokasi dari estimasi titik permulaan dari symbol OFDM, dampak dari error waktu bisa berbeda-beda.. Ada yang permulaan simbol yang tepat, sedikit cepat, terlalu cepat, dan permulaan simbol yang lambat. Tabel 1 menunjukkan pengaruh STO baik pada domain waktu ataupun frekuensi.

Tabel 1 Efek STO Pada Sinyal yang Diterima (Cho, Yong Soo; dkk, 2010)

\begin{tabular}{|l|c|c|}
\hline & $\begin{array}{c}\text { Sinyal } \\
\text { Diterima }\end{array}$ & $\mathrm{STO}(\delta)$ \\
\hline Domain Waktu & $\mathrm{y}(\mathrm{n})$ & $\mathrm{y}[\mathrm{n}+\delta]$ \\
\hline $\begin{array}{l}\text { Domain } \\
\text { Frekuensi }\end{array}$ & $\mathrm{Y}(\mathrm{k})$ & $y(k) e^{\frac{j 2 \pi k \delta}{N}}$ \\
\hline
\end{tabular}


Sedangkan Gambar 5 di bawah ini adalah berbagai macam efek STO dalam simbol OFDM.

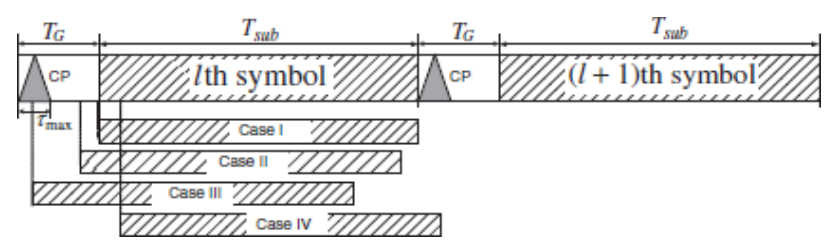

Gambar 5 Beberapa Kasus Berbeda dalam Starting Point simbol OFDM (Mathunarathan, 2013)

\subsubsection{Error Frekuensi}

Sinyal baseband mengirimkan sinyal yang dikonversi ke passband oleh modulasi pembawa dan kemudian dikonversi ke sinyal baseband dengan menggunakan sinyal pembawa lokal yang diharapkan sama dengan frekuensi pembawa pada penerima. Secara umum, ada dua jenis distorsi yang terkait dengan sinyal pembawa. Salah satunya adalah fase kebisingan karena ketidakstabilan generator sinyal pembawa yang digunakan pada pemancar dan penerima, yang dapat dimodelkan sebagai proses acak zero mean Wiener. Yang lainnya adalah frekuensi pembawa offset (CFO) yang disebabkan oleh frekuensi Doppler $f$ d.

CFO yang dinormalisasi didefinisikan dengan $\varepsilon$, yaitu perbandingan antara CFO terhadap jarak antara subcarrier $\Delta f$, diperlihatkan dengan:

$$
\varepsilon=\frac{f_{o f f}}{\Delta f}
$$

Tabel 2 Efek CFO Pada Sinyal yang Diterima (Cho, Yong Soo; dkk, 2010)

\begin{tabular}{|l|c|l|}
\hline & $\begin{array}{c}\text { Sinyal } \\
\text { Diterima }\end{array}$ & $\mathrm{CFO}$ \\
\hline Domain Waktu & $\mathrm{y}[\mathrm{n}]$ & $e^{j 2 \pi n \varepsilon / N} y[n]$ \\
\hline $\begin{array}{l}\text { Domain } \\
\text { Frekuensi }\end{array}$ & $\mathrm{Y}[\mathrm{k}]$ & $\mathrm{Y}[\mathrm{k}-\varepsilon]$ \\
\hline
\end{tabular}

\subsection{Sinkronisasi OFDM}

Terdapat 3 jenis Sinkronisasi OFDM, sebagai berikut :

1. Menggunakan Training Symbol (TP) pada domain waktu

2. Menggunakan korelasi $\mathrm{CP}$
3. Teknik blind tanpa memakai training symbol atau cyclic prefix.

Secara umum dari segi performansi dan kompleksitas, sinkronisasi dengan training symbol adalah teknik sinkronisasi yang paling baik, kekurangannya lebih banyak menggunakan badwidth karena ikut mengirimkan training symbol dalam datanya. CP yang lebih hemat bandwidth karena tidak mengirimkan symbol atau data tambahan training symbol dalam sinkronisasinya, kekurangannya dalam segi performansinya. Teknik yang ketiga yaitu blind technique tanpa CP yang sangat hemat bandwidth karena tidak membutuhkan CP dan TS dalam sinkronisasinya, namun performansi dan kompleksitasnya sangat tinggi. Gambar 6 di bawah ini adalah tahapan umum sinkronisasi pada OFDM.

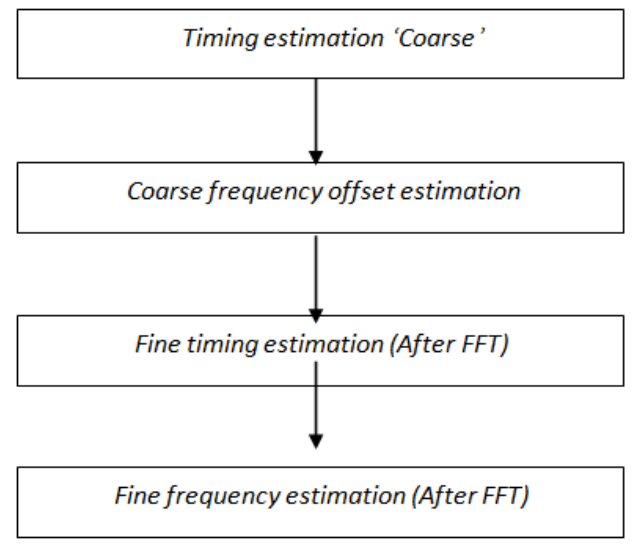

Gambar 6 Tahapan Sinkronisasi OFDM

\subsection{Teknik Estimasi pada Error Frekuensi (CFO)}

CFO adalah perbedaan frekuensi sinyal pada osilator pengirim dan penerima. Hal ini dapat terjadi karena pada antena pemancar ataupun antena penerima mengalami pergeseran frekuensi, sehingga frekuensi antara kedua nya menjadi tidak sama. Apabila frekuensi antara antena pemancar dan antena penerima tidak sama dapat mengganggu orthogonalitas carrier, sehingga dapat menyebabkan adanya Intercarrier Interference (ICI).

CFO bisa menjadi besar pada awal sinkronisasi, Sehingga dibutuhkan teknik estimasi yang meliputi range $\mathrm{CFO}$ yang besar. Range estimasi CFO bisa ditingkatkan dengan mengurangi jarak antara 2 blok korelasi sampel, bisa dilakukan dengan menggunakan training symbol berulang dengan periode yang lebih 
pendek (Cho, Yong Soo; dkk, 2010). D adalah integer yang mewakili rasio panjang simbol OFDM dengan pola berulang. Pengirim mengirimkan training symbol dengan pola berulang D pada domain waktu, bisa dibangkitkan dengan IFFT pada domain frekuensi dengan persamaan berikut (Cho, Yong Soo; dkk, 2010):

$$
X l[k]=\left\{\begin{array}{c}
\text { Am, if } k=D . i, i=0,1, \ldots,\left(\frac{N}{D-1}\right) \\
0, \text { lainnya }
\end{array}\right.
$$

\section{Perancangan dan Simulasi}

Penelitian ini merancang dan mensimulasikan estimasi offset frekuensi pada sinkronisasi OFDM. Software yang dipakai dalam simulasi penelitian ini adalah Matlab 2009 (Matlab 7.8.0.). Data masukan berupa sinyal OFDM dengan spesifikasi secara umum sebagai berikut:

1. Jumlah FFT : 1024

2. Jumlah Subcarrier : 64

3. Modulasi : QAM

4. Bandwidth sinyal OFDM dinormalisasi terhadap jarak antar subcarrier

5. Disimulasikan pada profil kanal vehicular dengan kecepatan $120 \mathrm{~km} / \mathrm{h}$

6. $12,5 \%$ guard interval

Ada beberapa tahapan dalam estimasi waktu dan estimasi offset frekuensi seperti tertuang dalam gambar 7 berikut:

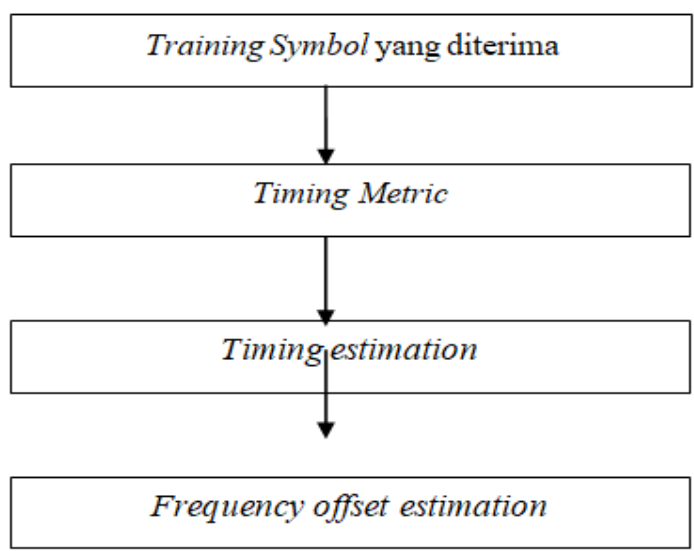

Gambar 7 Tahapan Perancangan dan Simulasi pada Estimasi Carrier Frequency Offset

\subsection{Deskripsi Blok Diagram}

Secara keseluruhan blok diagram terdiri dari input data, konversi data input dari serial ke parallel, modulasi data, IFFT, penambahan cyclic prefix, penambahan training symbol, konversi data dari parallel ke serial dan kemudian dikirimkan melalui kanal. Sedangkan pada penerima, terdapat proses data yang diterima diubah dari serial ke parallel, menghapus cyclic prefix dan training symbol, proses FFT, , demodulasi, mengubah data hasil demodulasi dari parallel ke serial, dan data dikembalikan ke bentuk data informasi semula.

\subsection{Timing Metric}

Perancangan sistem timing metric hingga timing estimation dapat dilihat pada gambar blok diagram 8 di bawah ini. Training symbol yang diterima diproses di korelator untuk mendapatkan timing metric. Korelator yang digunakan adalah korelator simetris dengan karakteristik statistik. Setelah didapatkan pola dari timing metric, digunakan timing metric maksimum yang merupakan estimasi dari timing offset.

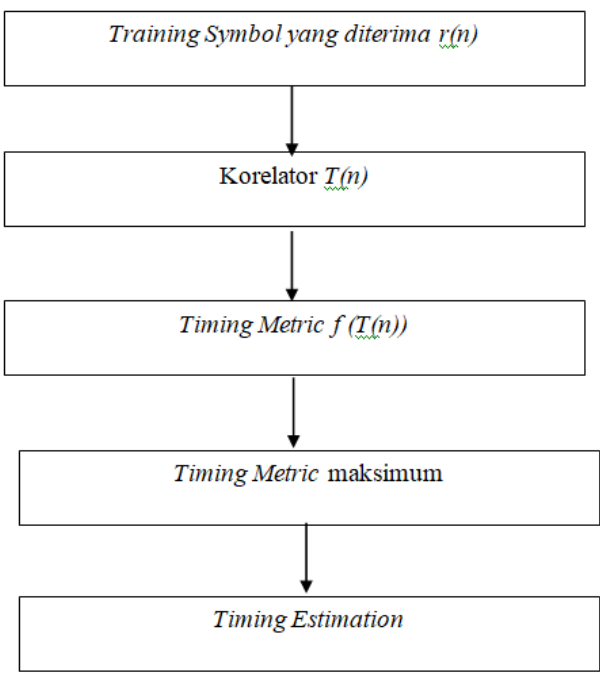

Gambar 8 Blok Diagram Perancangan Timing Estimation

Sebuah sistem OFDM dengan panjang FFT adalah $N f$, dimana sebanyak $N u(<N f)$ subcarrier digunakan untuk modulasi data. Untuk tujuan sinkronisasi, satu atau lebih training symbol dikirimkan. Rumusan korelasi simetris training symbol dinyatakan dalam (W. Dajin ; O. Wang, 2015)

$$
x_{p}^{x}\left(\frac{N_{F}}{2}-k\right)=x *_{p}\left(\frac{N_{E}}{2}+k\right), 1 \leq k \leq \frac{N_{F}}{2}-1
$$

Di mana $x_{p}(n), 0 \leq \mathrm{n} \leq N f-1$ adalah sinyal training symbol pada domain waktu. Training symbol ini memenuhi rumusan korelasi simetris yang bisa dibangkitkan dengan mengalokasikan 
PN sequence pada setiap subcarrier ke- $Q$ pada domain frekuensi

$X_{p}(k)=\left\{\begin{array}{cc} \pm 1 & \bmod (k, Q)=0 \\ n & \text { lnimmar }\end{array}\right.$

$X p(k)$ adalah sinyal training symbol pada subcarrier ke- $k$ pada domain frekuensi, dan $\bmod ($,) adalah fungsi modular ketika $\mathrm{Q}>1$, hasil dari training symbol memiliki fungsi berulang pada domain waktu sehingga terdiri dari bagian identik Q dengan panjang $\operatorname{Lr}(=N f / Q)$ sampel. Sebelum pengiriman training symbol, cyclic prefix dengan panjang $N g$ disisipkan. Setelah kanal multipath, sinyal yang diterima adalah:

$r(n)=e^{j \frac{3 m e n}{N_{F}}} \sum_{m=0}^{L c h} h(m) x_{p}(n-m)+w(n)$

$N F$ adalah jumlah FFT, $\varepsilon$ adalah carrier frequency offset (CFO) yang dinormalisasi terhadap jarak subcarrier, dan $w(n)$ adalah AWGN. $h=\left[h(0), \ldots, h(L c h)^{T}\right.$ adalah respon impuls dari kanal multipath dan Lch adalah panjang kanal.

\subsubsection{Korelator Simetris}

Berdasarkan persamaan (3.1), korelator simetris $T(n)$ bisa didefinisikan sebagai berikut:

$$
T(n)=\left|\sum_{k=1}^{\frac{N_{F}}{2}-1} r\left(n+\frac{N_{F}}{2}-k\right) r\left(n+\frac{N_{F}}{2}+k\right)\right|
$$

Pada kanal multipath dimana jalur pertama yang datang bukan jalur yang paling kuat, puncak maksimum (Tn) tertunda terhadap jalur yang paling kuat, yang akan menyebabkan error waktu. Untuk menentukan jalur kedatangan pertama secara tepat, digunakan timing metric berdasarkan karakteristik statistik pada korelator simetris.

Seperti yang terdapat pada gambar 8 sebelumnya, bahwa timing estimation didapat setelah menghitung timing metric. Timing metric maksimum yang didapatkan digunakan sebagai estimasi timing offset.

\subsection{Perancangan Estimasi Carrier Frequency Offset}

Untuk mengukur offset frekuensi berdasarkan data pada domain waktu, dibutuhkan identifikasi dan mengukur kemiringan fasa.
Dengan struktur replikasi training symbol, segmen perulangan waktu dalam domain waktu dapat digunakan untuk memperkirakan faktor fasa. Gambar 9 di bawah ini adalah blok diagram perancangan estimasi carrier frequency offset.

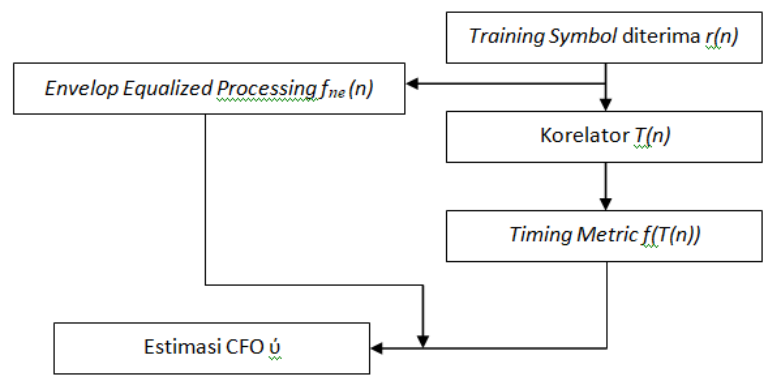

Gambar 9 Blok Diagram Perancangan Estimasi $\mathrm{CFO}$

\subsubsection{Envelope Equalized Processing (EEP)}

Pada sistem OFDM, training symbol digunakan untuk sinkronisasi waktu dan estimasi kanal yang dibangkitkan melalui DFT dalam bilangan kompleks

$$
X_{T}\left[=x_{T, 0} x_{T, 1, \ldots, x_{T, N-1}}\right]
$$

Di mana $x T, i$, dengan $i=0$ sampai $N-1$ adalah sampel dari training symbol pada domain waktu. Dengan faktor EEP, sampel yang diterima training symbol bisa dideskripsikan dengan

$$
\begin{aligned}
& r_{1}(n)=r_{T}(n) \cdot f_{n e}(n)=\left[y_{T}(n) e^{\frac{j a m v n}{N}}+w(n)\right] \cdot f_{n e}(n) \\
& =e^{j\left(\frac{a m v n}{N}\right)} \sum_{m=0}^{L-1} h_{m} x_{T, k-m} f_{n e}(n)+w(n) \cdot f_{n e}(n) \\
& =h_{0} e^{j\left(\frac{3 m v n}{N}\right)}+w_{2}(n)
\end{aligned}
$$

\subsubsection{Estimasi Nilai Offset Frekuensi}

Banyak Algoritma yang digunakan untuk estimasi offset frekuensi ini, kebanyakan dengan memakai periodogram. Offset frekuensi diestimasi dalam 3 langkah seperti yang ditunjukan oleh gambar 10 di bawah ini 


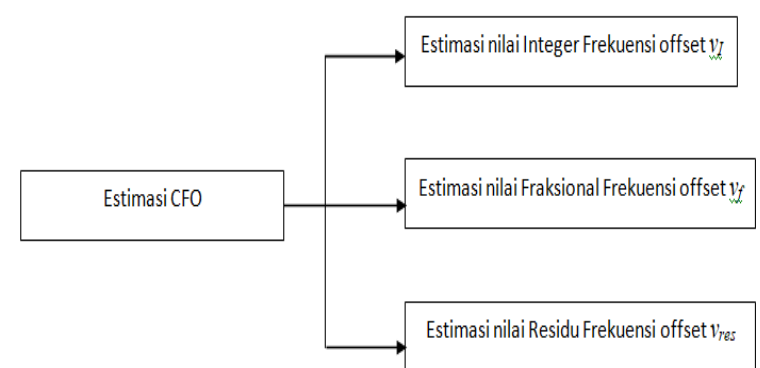

Gambar 10 Langkah Perancangan Estimasi CFO

Periodogram dari sinyal complex tone adalah pada frekuensi $v ́ I+v ́ f+0.5$ dan $v ́ I+v f-0.5$. Maka didapatkan:

$$
\begin{aligned}
& \frac{\sqrt{I_{t}\left(\hat{o}_{I}+\hat{b}_{f}+0.5\right.}-\sqrt{I_{z}\left(\hat{o}_{I}+\hat{b}_{f}-0.5\right.}}{\sqrt{I_{s}\left(\hat{o}_{I}+\hat{b}_{f}+0.5\right.}+\sqrt{I_{s}\left(\hat{b}_{I}+\hat{b}_{f}-0.5\right.}} \\
& =\frac{\left|\sin c\left(\pi\left(\hat{b}_{I}+v_{f}+0.5-v\right)\right)\right|-\left|\sin c\left(\pi\left(\hat{b}_{I}+\hat{b}_{f}-0.5-v\right)\right)\right|}{\left|\sin c\left(\pi\left(\hat{t}_{I}+v_{f}+0.5-v\right)\right)\right|+\left|\sin c\left(\pi\left(v_{I}+v_{f}-0.5-v\right)\right)\right|} \\
& =\frac{\sin c\left(\pi\left(0.5-v_{r e z}\right)\right)-\sin c\left(\pi\left(-0.5-v_{\text {res }}\right)\right) \mid}{\sin c\left(\pi\left(0.5-v_{\text {res }}\right)\right)+\sin c\left(\pi\left(-0.5-v_{\text {res }}\right)\right) \mid}=2 v_{\text {res }}
\end{aligned}
$$

Bagian residu bisa diestimasi dengan :

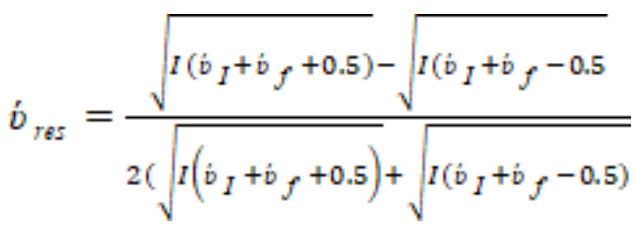

Estimasi Offset frekuensi bisa diperoleh dengan:

$$
\hat{v}^{\circ}=v_{f}+v_{I}+v_{\text {reg }}
$$

\section{Analisis Hasil Simulasi}

\subsection{Simulasi Estimasi Carrier Frequency Offset pada Timing Metric yang Tepat}

Pada bagian ini merupakan hasil simulasi estimasi offset frekuensi pada timing metric maksimum (tanpa pergeseran timing metric). TM yakni pada titik 1154 dengan berbagai nilai SNR dan range offset frekuensi input dari 0 sampai 25

\subsubsection{Estimasi CFO dengan SNR $30 \mathrm{~dB}$}

Hasil simulasi pada timing metric maksimum dengan SNR = $30 \mathrm{~dB}$ ditunjukan oleh gambar 11. Dapat dilihat titik estimasi CFO sudah mendekati stabil, hanya terdapat sedikit error yang pada estimasi CFO. $\mathrm{SNr}=30 \mathrm{~dB}$ merupakan SNR tertinggi yang dimasukan dalam simulasi ini.

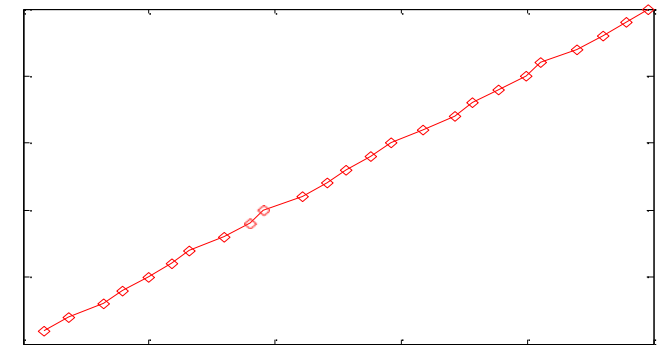

Gambar 11 Estimasi CFO dengan SNR 30 dB

\subsubsection{Estimasi CFO dengan SNR $15 \mathrm{~dB}$}

Pada gambar 12 di bawah ini adalah grafik hasil simulasi pada timing metric maksimum dengan SNR $=15 \mathrm{~dB}$. Terdapat banyak kesalahan dalam estimasi offset frekuensi karena nilai SNR yang semakin rendah. Ada penurunan dari estimasi sebelumnya, SNR $30 \mathrm{~dB}, 25 \mathrm{~dB}, 20 \mathrm{~dB}$.

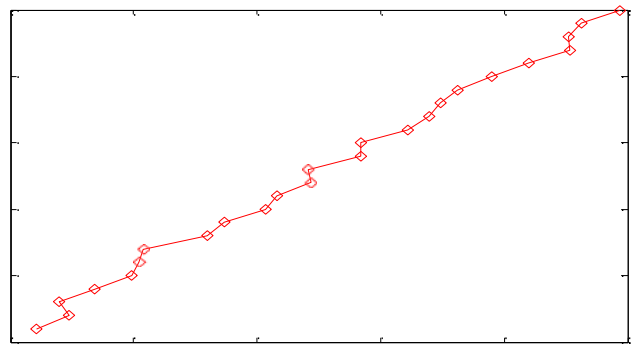

Gambar 12 Estimasi CFO dengan SNR 15 dB

\subsubsection{Estimasi CFO dengan SNR $5 \mathrm{~dB}$}

Grafik hasil simulasi pada timing metric maksimum dengan SNR $=5 \mathrm{~dB}$ ditunjukan oleh gambar 13. Terjadi penurunan dari estimasi sebelumnya, di mana terdapat banyak kesalahan dalam estimasi offset frekuensi karena nilai SNR yang sangat rendah.

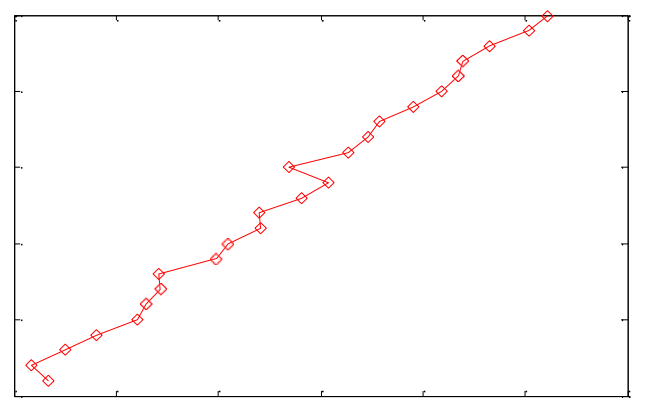

Gambar 13 Estimasi CFO dengan SNR 5 dB

\subsubsection{Perbandingan Simulasi Estimasi Carrier Frequency Offset dengan SNR = $30 \mathrm{~dB}$}

Pada simulasi ini juga dilakukan perbandingan antara estimasi CFO pada penelitian 
ini dan pestimasi CFO pada metode referensi (Suyoto, 2015). Perbandingan antara simulasi estimasi CFO dari metode referensi dengan metode pada penelitian ini ditunjukan oleh gambar 14 di bawah ini
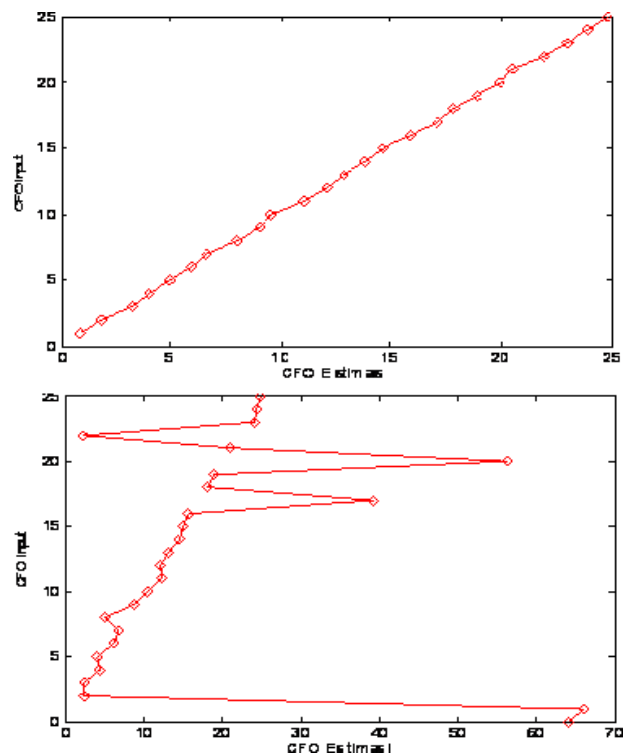

Gambar 14 Perbandingan CFO dalam Penelitian ini (atas) dan Metode Referensi (bawah)

Pada gambar 14 dapat dilihat bahwa terjadi peningkatan estimasi CFO dari metode referensi (Suyoto, 2015) dimana estimasi CFO stabil dan akurat pada range $\mathrm{CFO}=2$ sampai dengan $\mathrm{CFO}=$ 12. Sedangkan range estimasi CFO pada penelitian ini lebih besar.

\subsubsection{Perbandingan nilai MSE Carrier Frequency Offset Terhadap nilai SNR}

Grafik hasil simulasi perbandingan nilai mean square error (MSE) terhadap nilai Signal to Noise Ratio (SNR) dapat dilihat pada gambar 15 di bawah ini

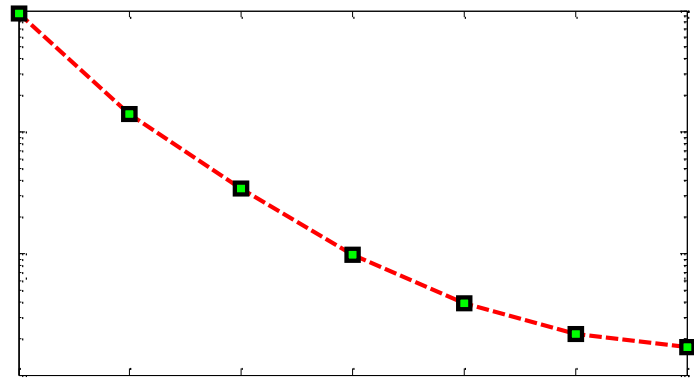

Gambar 15 Perbandingan Mean Square Error Terhadap Perubahan SNR
Pada grafik dapat dilihat bahwa nilai MSE ketika $\mathrm{SNR}=0 \mathrm{~dB}$ sampai $\mathrm{SNR}=30 \mathrm{~dB}$ mengalami penurunan nilai secara bertahap Di mana ketika SNR diatas $25 \mathrm{~dB}$ maka MSE mendekati $10^{-5}$.Dapat dilihat bahwa semakin tinggi nilai SNR, maka semakin kecil nilai MSE yang didapat.

Grafik hasil perbandingan nilai MSE dari estimasi CFO terhadap CFO input terhadap perubahan nilai SNR antara metode referensi dengan penelitian ini ditunjukan oleh gambar 16 . Ada sedikit peningkatan yang ada dalam metode penelitian ini. Pada metode referemsi, timing estimation dianggap sempurna, tidak memiliki error waktu. Sedangkan pada penelitian ini timing estimation menggunakan metode timing metric statistic dimana penentuan timing metric menggunakan persamaan statistic.

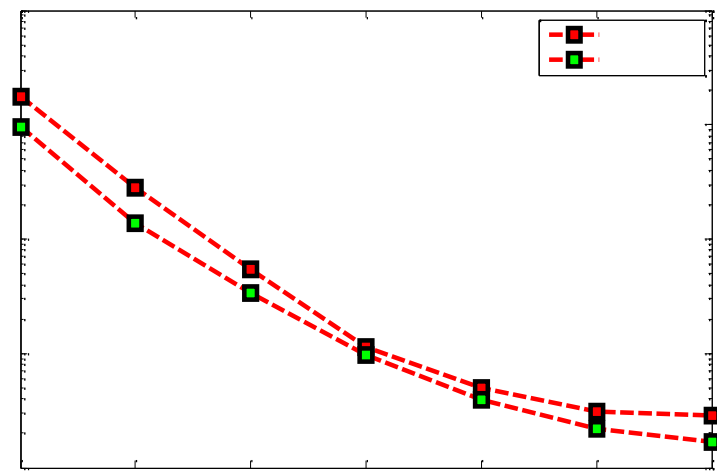

Gambar 16 Perbandingan Mean Square Error Terhadap Perubahan SNR

4.2 Estimasi Carrier Frequency Offset pada Timing Metric $=1154$ dan Timing Metric = 1157

Grambar 17 di bawah ini adalah grafik hasil simulasi pada timing metric 1154 .

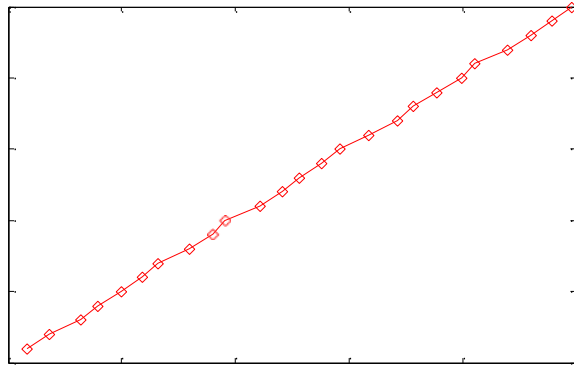

Gambar 17 Estimasi CFO dengan timing metric 1154 dan SNR $30 \mathrm{~dB}$ 


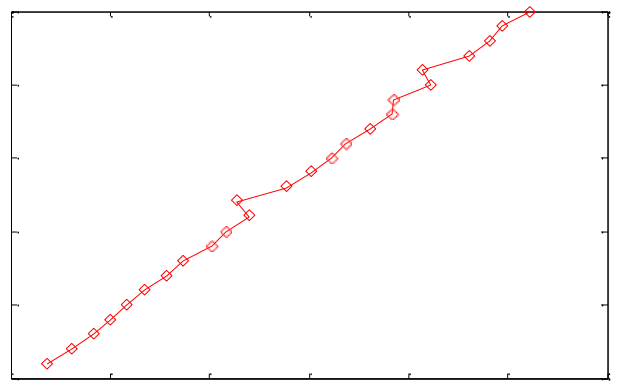

Gambar 18 Estimasi CFO dengan timing metric 1157 dan SNR $30 \mathrm{~dB}$

Gambar 18 adalah grafik hasil simulasi pada timing metric 1157 (bergeser 3 titik ke kanan dari timing metric seharusnya yaitu 1154). grafik terlihat sudah lebih beraturan dan nilainya linear terhadap penambahan nilai CFO input, tapi masih terdapat banyak kesalahan nilai dalam estimasi offset frekuensi karena kesalahan timing metric yang digunakan. Contoh : pada CFO masukan $=5$, CFO estimasi sekitar 6.5. Dari beberapa nilai estimasi timing metric yang disimulasikan yang paling mendekati dengan timing metric yang tepat (1154) adalah ketika timing metric 1157 karena nilai timing metricnya yang cukup besar yaitu 40 . $3.935 \times 10^{12}$

\section{Kesimpulan}

Beberapa kesimpulan dari penelitian ini:

1. Hasil dari estimasi Carrier Frequency Offset (CFO) dipengaruhi oleh posisi timing metric, dimana Estimasi CFO akan akurat ketika posisi timing metric yang digunakan berada pada titik maksimum.

2. Range Carrier Frequency Offset (CFO) yang didapatkan pada penelitian ini adalah $\mathrm{CFO}=0$ sampai dengan $\mathrm{CFO}=25$

3. Range Mean Square Error (MSE) estimasi Carrier Frequency Offset (CFO) yang didapatkan adalah $9.43 \times 10^{-3}$ pada SNR masukan $0 \mathrm{~dB}$ sampai $1.687 \times 10^{-5}$ pada SNR masukan $30 \mathrm{~dB}$.

\section{Saran}

Salah satu saran untuk penelitian selanjutnya adalah mencoba simulasi estimasi CFO dengan training symbol dengan faktor EEP yang lebih kompleks. Diharapkan dengan factor EEP yang lebih komplek dapat meningkatkan nilai SNR dan menurunkan MSE dan juga dapat dipakai pada kondisi kanal yang lebih kompleks.

\section{Referensi}

Cho, Y. H., \& Park, D. (2014). Timing Estimation Based on Statistical Change of Symmetric Correlator for OFDM Systems. Communication Letters. IEEE vol. 17 no. 2 , 397-400.

Cho, Yong Soo; dkk. (2010). MIMO OFDM Wireless Communication with MATLAB. Singapore: John Willey \& Sons.

Leis, J. W. (2018). Communiocation Systems Principles Using MATLAB. New Jersey: Wiley Blackwell.

M.S Maneesha; Suma Sekhar ; Sakuntala. (2017). Complementary sequence based CFO Estimation for OFDM Systems Using Simulink. 2017 international Conference on Intelligent Computing, Instrumentation and Control Technologies (p. 64). India: IEEE.

Mathunarathan, V. (2013). Simulation of Dugital Communication Systems using MATLAB. India: Mathuranathan Viswanathan at Smashword.

Srikanth, Kumaran V; Manikan. (2010). Orthogonal Frequency Divison Multiple Access. India: Anna University Press.

Suyoto. (2015). Comparison Study on Time Synchronization Method for OFDM Mobile System. INIKOM, Vol 8, no 1, 301.

Suyoto; A.Kurniawan. (2015). Timing Estimation Based on Normalized 3rd-order central moment for Symmetric Correllator in OFDM Systems. International Conference on Information Technology Systems and Innovation (p. 44). Bandung: IEEE.

Suyoto; Sugihartono. (2015). Improved Timing Estimation Based on Symmetric CorrelatorUsing Statistical change of Correlator for OFDM Systems. IC3INA (p. 100). Bandung: IEEE.

W. Dajin ; O. Wang. (2015). An Approximate Method of Carrier Frequency Offset Estimatimation for OFDM Systems. the 80th VehicularTechnology (p. 299). Canada: IEEE. 
